\title{
Marlo Johnston, Lettres inédites de Maupassant à la comtesse Potocka
}

Damiano Sinfonico

\section{(2) OpenEdition}

1 Journals

\section{Edizione digitale}

URL: http://journals.openedition.org/studifrancesi/6394

DOI: $10.4000 /$ studifrancesi.6394

ISSN: 2421-5856

\section{Editore}

Rosenberg \& Sellier

\section{Edizione cartacea}

Data di pubblicazione: 1 novembre 2010

Paginazione: 580-581

ISSN: 0039-2944

\section{Notizia bibliografica digitale}

Damiano Sinfonico, «Marlo Johnston, Lettres inédites de Maupassant à la comtesse Potocka», Studi Francesi [Online], 162 (LIV | III) | 2010, online dal 30 novembre 2015, consultato il 11 janvier 2021. URL: http://journals.openedition.org/studifrancesi/6394 ; DOI: https://doi.org/10.4000/studifrancesi.6394

Questo documento è stato generato automaticamente il 11 janvier 2021.

\section{(c) (i) (9)}

Studi Francesi è distribuita con Licenza Creative Commons Attribuzione - Non commerciale - Non opere derivate 4.0 Internazionale. 


\title{
Marlo Johnston, Lettres inédites de Maupassant à la comtesse Potocka
}

\author{
Damiano Sinfonico
}

NOTIZIA

MARLO JOHNSTON, Lettres inédites de Maupassant à la comtesse Potocka, in «Histoires littéraires. Revue trimestrielle consacrée à la littérature française des $\mathrm{XIX}^{\mathrm{e}}$ et $\mathrm{XX}^{\mathrm{e}}$ siècles», n. 40, octobre-novembre-décembre 2009, pp. 59-106.

1 Sono pubblicate lettere e biglietti, quasi un centinaio, che Maupassant inviava alla contessa Potocka, italiana sposata a un nobile polacco, amica di intellettuali e scrittori. Della corrispondenza, mantenuta nel periodo compreso tra il 1883 e il 1891, non ci sono tracce di lettere scritte dalla contessa. Le lettere sono inedite, tranne sei già pubblicate nella Correspondance di Maupassant curata da Jacques Suffel nel 1973. 